\title{
Evolução da consciência fonológica em alunos de ensino fundamental $* * *$
}

\author{
Phonological awareness improvement in primary school students
}

Maria Sílvia Cárnio* (mscarnio@usp.br)

Daniele dos Santos**

\begin{abstract}
*Fonoaudióloga. Doutora em Lingüística pela Faculdade de Filosofia, Letras e Ciências Humanas da Universidade de São Paulo. Docente do Programa de Pós-Graduação em Ciências - Área de Fisiopatologia Esperimental da Faculdade de Medicina da Universidade de São Paulo.

**Fonoaudióloga. Mestranda em Ciências - Área de Fisiopatologia Experimental da Faculdade de Medicina da Universidade de São Paulo

***Trabalho Realizado no Curso de Fonoaudiologia da Faculdade de Medicina da Universidade de São Paulo .
\end{abstract}

Artigo de Pesquisa

Artigo Submetido a Avaliação por Pares

Conflito de Interesse: não

\begin{abstract}
Background: phonological awareness in primary school students. Aim: to verify the improvement of phonological awareness in primary school students after a speech and language stimulation program. Method: 20 students with the worst results in the first literacy exam were selected. Phonological awareness tests were analyzed at the beginning and at the end of the stimulation program. Results: most of the subjects demonstrated to have a notion about phonological awareness activities. Conclusion: students demonstrated improvement, suggesting the effectiveness of the program.
\end{abstract}

Key Words: Phonological Awareness; Literacy; Primary School.

\section{Resumo}

Tema: consciência fonológica em alunos de ensino fundamental. Objetivo: analisar evolução de consciência fonológica em alunos do ensino público fundamental após programa de estimulação fonoaudiológica. Método: foram selecionados 20 alunos com piores resultados na avaliação inicial de letramento. Foram analisadas as provas de consciência fonológica no início e final do programa de estimulação. Resultados: a maioria dos sujeitos demonstrou noção de atividades de consciência fonológica. Conclusão: os alunos apresentaram evolução, sugerindo eficácia do programa.

Palavras-Chave: Consciência Fonológica; Letramento; Ensino Fundamental.

Recebido em 16.05.2003.

Revisado em 11.11.2003; 22.03.2004;

10.08.2004; 17.12.2004; 18.03.2005;

13.05.2005.

Aceito para Publicação em 27.05.2005.

1 CÁRNIO, M. S.; SANTOS, D. Phonological awareness improvement in primary school students (original title: Evolução da consciência fonológica em alunos de $\sum 3$ ensino fundamental). Pró-Fono Revista de Atualização Científica, Barueri (SP), v. 17, n. 2, p. 195-200, maio-ago. 2005. 


\section{Introduction}

A theoretical review of the studies about reading and writing acquisition evidences that in the past years many significant conceptual changes occurred.

The specific definition of alphabetization must be clarified since many researches found that this term was not enough to define and include all processes involved in the reading and writing acquisition, raising a new term - the literacy (Soares, 1998).

According to Soares (1998), alphabetization and literacy are distinct, however inseparable actions. The alphabetization consists in the action of enabling the individual to read and write, while literacy focuses the social aspect of writing appropriation and its social practice.

Generally, when children start school they already master the oral language since they have had world knowledge and life experiences involving dialogic social interactions that are permeated by literacy practices. These practices complement one another and are constituted through orality and writing (Marcuschi, 2001).

Reading and writing acquisition can be very pleasurable if the child is provided with literacy experiences through informal social situations that allow the social use of writing, its importance and its relation to the orality. However, the profile of children who attend state schools is rarely like this, especially in the school where the speech-language program "Programa Escola" is developed. Generally, only a few children attend kindergarten. The majority of them are from a low socio-economic level; frequently they do not know their own name and surname when orally requested nor imagine how this identity mark could be written. Thus, it may be quite difficult for this specific population to consider that there is another language modality, the written one, that can be acquired and involves other skills.

In this context, one of the most difficult metalinguistic abilities to be understood by these children is the phonological and phonemic awareness.

For Blachman (1991), phonological awareness is the ability to recognize and to manipulate phonological segments in words, and it is considered a basic precursor for the writing development.

This is a polemic issue, and despite many authors assert the importance of the phonological awareness relating it with reading decoding and comprehension abilities (Gilbertson \& Bramlett, 1998), it can not be considered a determinant factor in the alphabetic principle discovery, once it is not enough for the reading and writing acquisition (Capellini \& Ciasca, 2000; Capovilla, 2002b). Nevertheless, many of these authors affirm the existence of a correlation between alphabetization and phonological awareness (Capovilla, 2002a).

Furthermore, some studies found that the children's performance in phonological awareness increases according to the schooling level (Cielo, 2002).

Considering these studies, an interest in verifying the profile of children from the first and second grades of a state school regarding the phonological awareness, as well as their improvement after a preventive program involving literacy practices with emphasis in oral narrative and phonological awareness emerged.

The aim of this study was to analyze the relevant aspects of the phonological awareness development in 20 first and second grades students of a public primary school.

The specific goals were:

- to verify the effect of a preventive speechlanguage program in oral and written language in the development of phonological awareness; - to verify the phonological awareness evolution.

\section{Method}

This article is an integrant part of a research approved by the Research Commission of the Speech and Hearing Department of the University of São Paulo (process number 198). The parents of all subjects signed the Informed Consent Term allowing the conduction of the research and the publication of its results according to the Resolution 196/96 of the National Committee on Research Ethics (Conep).

\section{Subjects}

Subjects were selected through the analysis of the initial evaluations performed with 109 first and second grades students of a State primary school during 1999.

Twenty subjects $(18,34 \%)$ who presented the lowest scores in the initial literacy evaluation and who also performed the final evaluation were selected; $50 \%$ were female; 12 subjects were from the first grade A, seven from the first grade B and one from the second grade. The mean age of the 
subjects was $7 ; 4$, varying from $6 ; 6$ to $8 ; 10$. Due to the similar performance of the subjects regarding the literacy practices and to the small sample, all subjects were placed in only one group allowing the statistical analysis.

\section{Material}

Literacy and phonological awareness protocols elaborated and used by the School Program, under the responsibility of Braga et al., 1998.

The literacy protocol comprises three parts: written code knowledge, with pairing, simple classification, seriation, and double classification tasks; written code use, with letters naming, words and sentences reading, Name and familiar words writing, letters and words writing, and knowledge of word's internal structure tasks; and print visual stimuli knowledge, with labels recognition and related words and sentences reading tasks.

The phonological awareness protocol consists of 14 tasks: rhyme, onset, rhyme conservation, onset conservation, phonemic counting, phonemic substitution, phonemic segmentation, blending, sound deletion, specification of deleted sound, sound-word relation, and word-word relation.

\section{Procedures}

\section{Initial evaluation}

The students' protocols of the "Programa Escola" were analyzed and those fulfilling the inclusion criteria of performance mentioned above were selected.

The evaluations were conducted by research assistants specially trained and supervisioned by the responsible professor. The evaluations were performed individually in one of the school's classroom. The following presentation order of tasks was obeyed.

The following instructions were given for the literacy protocol application: in the pairing task the child was asked to separate the cards placed on a table in three groups and to point which one contained letters, words and numbers. In the simple classification task the child was asked to separate the cards with capital and cards small letters and then, to separate the cards with a printed word and with a hand-writing word. In the seriation task, the child was asked to pick up two cards with similar numbers, three cards with different letters, two words with the letter E, two different numbers, two vowels and one consonant, and two words beginning with the letter B. In the double classification task the child receives a sheet with two columns containing figures, letters, numbers and words and he is asked to reproduce the element that is repeated in both columns. In the letter naming task the child is asked the name of 10 letters presented one by one and a word beginning with each letter named by him. In the words and sentences reading, the child is asked to read 10 words and 10 sentences. In the Name and familiar words writing, the child is asked to write his first name and the name of another family person, or any other word the child knows. In the letters and words writing the child is asked to write three different letters and one word starting with each letter written. In the knowledge of word's internal structure, the child is asked to write ten words dictated by the examiner and to create new words with the same letters as the dictated ones. In the labels recognition, ten cards with products labels are presented and the child is asked whether he knows them or not; if the answer is yes, the child is asked to justify it. And in the reading of words and sentences related to the labels, the child is asked to read ten words and ten sentences with issues related to each recognized label.

For the phonological awareness protocol, the following instructions were given: in the soundword relation, it was asked if the word "pato" started with the letter " $p$ ". In the word-word relation, it was asked if the word "pente" started with the same letter as the word "pato". In the rhyme, it was asked whether the word "pato" rhymed with "sapato". In the sound isolation, it was asked which letter the word "lápis" started with. In the phonemic counting, it was asked how many sounds the word "chuva" had. In the phonemic segmentation, it was asked which were the sounds of the word "sapo". In the blending, it was asked which was the word formed by the phonemes $/ \mathrm{f} / / \mathrm{a} / / \mathrm{k} / / \mathrm{a} /$. In the deletion it was asked which word was formed when the " $m$ " was taken away of the word "mar". In the specification of the deleted phoneme, it was asked which sound had to be removed of the word "pai" in order to form the word "ai". In the phoneme substitution, it was asked which word was formed when we substitute the phoneme $/ \mathrm{m} /$ by the $/ \mathrm{p} /$ in the word "mão". In the rhyme conservation four rhyming words were said and the child was asked to tell another one that fit in the group. In the onset, it was asked whether the word "lupa" started like the word "luva". In the onset conservation four words starting with the same sound were said and the child was asked to tell another one that fit in the group. 
The data from the evaluations were tabulated and statistically analyzed by a professional.

After the evaluation, the children who presented oral or written language disorders were counseled and referred.

Preventive speech-language program in oral and written languages

Five stimulation sessions were given to groups of five-six children randomly selected. The sessions were performed in the school classrooms, with at the most five groups per classroom.

The research assistants chose the material to be used according to the group's necessity, that is, the students initiating the alphabetization process had literacy and initial abilities of phonological awareness activities, such as rhyme. Students with some knowledge of the relation between orality and writing already established had more sophisticated metalinguistic skills activities, such as segmentation and phonemic awareness. In all sessions phonological awareness, literacy and oral narrative aspects were considered.

Games and a variety of materials, including words and sentences taken from texts employed in the oral narrative were used for the phonological awareness practice. The oral narrative was performed using the scaffolding technique (Hoffman, 1997) applied by the research assistants who read literature stories, preferable with pictures and written text. Afterwards, using paper and pencil, these stories were retold through written schemes made by the child and the research assistants, emphasizing the aspects that were less noticed by the children (for example: the character's features, temporal sequence, etc.).

\section{Final evaluation}

The same material and procedures were used in the final evaluation, except the literacy protocol that was used only for the selection of the subjects.

Analysis procedure

Analysis criteria for the phonological awareness.

The same analysis and score criteria adopted for the "Programa Escola" were used. This criterion consisted in verifying whether the student performed correctly or not the phonological awareness tasks. The students responses for each task were classified into YES for adequate and NO for inadequate. Each task performed adequately scored one point.

\section{Results}

\section{Statistical analysis}

The following statistical tests were used: two proportions equality test, chi-square test, and two averages equality test known as T-test. The significance level used was $0,1(10 \%)$ due to the reduced sample size.

\section{Phonological awareness}

Table 1 shows a quantitative comparison for the number of phonological awareness tasks performed in the initial and final evaluations.

It can be seen in Table 1 a statistically significant mean difference between the number of phonological awareness tasks performed in the initial evaluation $(2,35)$ and the number of tasks performed in the final evaluation $(5,41)$.

The most produced tasks in the initial evaluation were sound-word relation and word-word relation $(52,9 \%)$; and in the final evaluation, the most produced task was rhyme $(94,1 \%)$ as shows Table 2.

Table 3 compares all tasks, two by two, aiming at verifying which of them present significant statistical difference.

The most frequent tasks in both evaluations were already observed (Table 2). Now, it can be seen that the tasks sound-word relation, word-word relation and rhyme don't present significant statistical difference between them (Table 3).

Table 4 shows the p-values of the evaluations comparisons for each one of the tasks.

It can be observed that there is a proportional difference between the initial and final evaluations in some tasks (rhyme, onset, phonemic counting, phonemic segmentation, sound isolation, soundword relation, word-word relation and specification of deleted phoneme), in which the proportion in the final evaluation is greater than in the initial one.

TABLE 1. Quantitative analysis of the phonological awareness tasks in both evaluations.

\begin{tabular}{ccc}
\hline & \multicolumn{2}{c}{ Número de Tarefas de Consciência Fonológica } \\
\hline média & Avaliação Inicial & Avaliação Final \\
\hline desvio padrão & 2,35 & 5,41 \\
tamanho & 1,87 & 2,50 \\
p-valor & 17 & 17 \\
& \multicolumn{3}{c}{$<0,001^{*}$} \\
\hline
\end{tabular}

$*=\mathrm{p}$. valor significante. 
TABLE 2. Performances in the phonological awareness tasks in the initial and final evaluations.

\begin{tabular}{cccccccc|c|c|c|c|c|c|c|c|c}
\hline & & $\mathrm{RI}$ & $\mathrm{ON}$ & $\mathrm{CR}$ & $\mathrm{CO}$ & $\mathrm{CF}$ & $\mathrm{SF}$ & $\mathrm{SG}$ & $\mathrm{FE}$ & $\mathrm{DE}$ & $\mathrm{IS}$ & PP & SP & EA \\
\hline avaliação & $\mathrm{N}$ & 8 & 5 & 1 & 1 & 1 & 1 & 0 & 3 & 1 & 1 & 9 & 9 & 0 \\
inicial & $\%$ & 47,1 & 29,4 & 5,9 & 5,9 & 5,9 & 5,9 & 0 & 17,6 & 5,9 & 5,9 & 52,9 & 52,9 & 0 \\
& $\mathrm{~N}$ & 16 & 12 & 0 & 0 & 7 & 4 & 5 & 4 & 3 & 5 & 14 & 15 & 7 \\
avaliação & final & $\%$ & 94,1 & 70,6 & 0 & 0 & 41,2 & 23,5 & 29,4 & 23,5 & 17,6 & 29,4 & 87,5 & 88,2 & 41,2 \\
\hline
\end{tabular}

Legenda: $\mathrm{RI}=$ rima; $\mathrm{ON}=$ onset $\mathrm{CR}=$ conservação de rima; $\mathrm{CO}=$ conservação de onset CF = contagem fonêmica; $\mathrm{SF}=$ substituição fonêmica; SG = segmentação fonêmica; FE = fechamento; DE = deleção; IS = isolamento de som; SP = relação som-palavra; PP = relação palavra-palavra; $\mathrm{EA}=$ especificar fonema apagado.

TABLE 3. P-values of the phonological awareness tasks in the initial and final evaluations.

\begin{tabular}{|c|c|c|c|c|c|c|c|c|c|c|c|c|}
\hline & RI & ON & CR & $\mathrm{CO}$ & $\mathrm{CF}$ & SF & SG & $\mathrm{FE}$ & $\mathrm{DE}$ & IS & SP & PP \\
\hline ON & $0,083^{*}$ & & & & & & & & & & & \\
\hline CR & $\begin{array}{c}< \\
0,001 *\end{array}$ & $\underset{0,001 *}{<}$ & & & & & & & & & & \\
\hline $\mathrm{CO}$ & $\underset{0,001^{*}}{<}$ & $\underset{0,001 *}{<}$ & 1,000 & & & & & & & & & \\
\hline $\mathrm{CF}$ & $\stackrel{<}{<, 001^{*}}$ & $0,024 *$ & $0,012^{*}$ & $0,012^{*}$ & & & & & & & & \\
\hline SF & $\underset{0,001 *}{<}$ & $0,002 *$ & $0,087^{*}$ & $0,087^{*}$ & 0,355 & & & & & & & \\
\hline SG & $\stackrel{<}{<, 001 *}$ & $0,002^{*}$ & $0,087^{*}$ & $0,087^{*}$ & 0,355 & 1,000 & & & & & & \\
\hline FE & $\stackrel{<}{<, 001^{*}}$ & $\stackrel{<}{<}$ & $0,024^{*}$ & $0,024 *$ & 0,771 & 0,525 & 0,525 & & & & & \\
\hline $\mathrm{DE}$ & $\begin{array}{c}< \\
0,001 *\end{array}$ & $\begin{array}{c}< \\
0,001 *\end{array}$ & 0,163 & 0,163 & 0,203 & 0,720 & 0,720 & 0,323 & & & & \\
\hline IS & $\stackrel{<}{<, 001 *}$ & $0,005^{*}$ & $0,046^{*}$ & $0,046^{*}$ & 0,549 & 0,742 & 0,742 & 0,758 & 0,493 & & & \\
\hline SP & 0,936 & 0,100 & $\underset{0,001 *}{<}$ & $\stackrel{<}{<}$ & $\stackrel{<}{<, 001 *}$ & $\stackrel{<}{<, 001 *}$ & $\begin{array}{c}< \\
0,001 *\end{array}$ & $\begin{array}{c}< \\
0,001 *\end{array}$ & $\underset{0,001 *}{<}$ & $\underset{0,001^{*}}{<}$ & & \\
\hline PP & 0,843 & $0,056^{*}$ & $\underset{0,001^{*}}{<}$ & $\underset{0,001^{*}}{<}$ & $\stackrel{<}{<, 001 *}$ & $\underset{0,001 *}{<}$ & $\stackrel{<}{<, 001 *}$ & $\begin{array}{c}< \\
0,001 *\end{array}$ & $\underset{0,001 *}{<}$ & $\underset{0,001 *}{<}$ & 0,786 & \\
\hline EA & $\begin{array}{c}< \\
0,001^{*}\end{array}$ & $\begin{array}{c}< \\
0,011^{*}\end{array}$ & $0,024^{*}$ & $0,024^{*}$ & 0,771 & 0,525 & 0,525 & 1,000 & 0,323 & 0,758 & $\begin{array}{c}< \\
0,001 *\end{array}$ & $\begin{array}{c}< \\
0,001 *\end{array}$ \\
\hline
\end{tabular}

Legenda: $*$ = p. valor significante; $\mathrm{RI}=$ rima; $\mathrm{ON}=$ onset $; \mathrm{CR}=$ conservação de rima; $\mathrm{CO}=$ conservação de onset , $\mathrm{CF}=$ contagem fonêmica; SF = substituição fonêmica; SG = segmentação fonêmica; FE = fechamento; DE = deleção; IS = isolamento de som; SP = relação som-palavra; $\mathrm{PP}=$ relação palavra-palavra; $\mathrm{EA}=$ especificar fonema apagado.

TABLE 4. Comparison of the phonological awareness tasks in both evaluations.

\begin{tabular}{|c|c|c|}
\hline & Avaliação Inicial & Avaliação Final \\
\hline rima & \multicolumn{2}{|c|}{$0,003 *$} \\
\hline onset & \multicolumn{2}{|c|}{$0,016 *$} \\
\hline conservação de rima & \multicolumn{2}{|c|}{0,310} \\
\hline conservação de onset & \multicolumn{2}{|c|}{0,310} \\
\hline contagem fonêmica & \multicolumn{2}{|c|}{$0,015^{*}$} \\
\hline substituição fonêmica & \multicolumn{2}{|c|}{0,146} \\
\hline segmentação fonêmica & \multicolumn{2}{|c|}{$0,015 *$} \\
\hline fechamento & \multicolumn{2}{|c|}{0,671} \\
\hline deleção & \multicolumn{2}{|c|}{0,286} \\
\hline isolamento de som & \multicolumn{2}{|c|}{$0,072 *$} \\
\hline relação som-palavra & \multicolumn{2}{|c|}{$0,031 *$} \\
\hline relação palavra-palavra & \multicolumn{2}{|c|}{$0,009 *$} \\
\hline especificar fonema apagado & \multicolumn{2}{|c|}{$0,003 *$} \\
\hline
\end{tabular}

\section{Discussion}

Concerning the phonological awareness, it could be observed that there is a statistically significant mean difference between the initial and final evaluations (Table 1) and in the comparisons performed between the initial and final evaluations in the rhyme, onset, phonemic counting, phonemic segmentation, sound isolation, sound-word relation, word-word relation and specification of deleted phoneme tasks (Table 4), indicating an evolution of the students in these aspects.

These data suggest the efficacy of the preventive speech-language program in oral and written languages concerning the development of phonological awareness, once literacy practices were developed based on oral and written activities. 
Furthermore, some literature data (Bryant et al., 2000; Godoy, 2003; Savage at al., 2003; Savage \& Carless, 2004) affirm that there is a relationship between reading and writing acquisition and phonological awareness development.

Although it was not the purpose of this study, the oral narrative work performed, following the scaffolding technique (Hoffman, 1997), demonstrated to be efficient for the development of the relation between orality and writing, improving the phonological and phonemic awareness of children with disorders in this area.

The most performed tasks by the students in the initial evaluation were: sound-word relation and word-word relation; in the final evaluation, the most used task was rhyme (Table 2). However, it was verified that the proportion of these three tasks mentioned did not present significant statistical difference (Table 3). The appearance of these three tasks as the most used ones agrees with the literature that affirms that they are considered the easiest ones by the subjects (Cielo, 2002), since they reproduce the syllabic form as taught in schools, except the sound-word relation task.

\section{Conclusion}

The statistical analysis allows to observe that, concerning the phonological awareness, the subjects had a significant average improvement in the majority of the tasks performed, suggesting a correlation between the reading and writing acquisition and the phonological awareness development, as well as an efficacy of the preventive speech-language program in oral and written languages.

Agradecimentos: à Fapesp pela Bolsa de Iniciação Científica concedida (processo número 99/12736-2); aos alunos do Curso de Fonoaudiologia da FMUSP, turma XXII, pela coleta dos dados; à equipe da Escola Estadual J. A. A., em especial às professoras Fátima, Débora, Sandra, Edilene, Claudete e Vera, pela participação e colaboração no programa; às fonoaudiólogas Scheila Maria Leão Braga, Sulamy M. Castelo Branco e Maria Cecília Periotto pela elaboração dos protocolos originais do Programa Escola e pelas diretrizes iniciais do mesmo.

\section{References}

BLACHMAN, B. A. Early intervention for children's reading problems: clinical applications of the research in phonological awareness. Topics in Language Desorders, v. 12, n. 1, p. 51-65, 1991.

BRAGA, S. M. L.; CASTELO-BRANCO, S. M C.; PERIOTTO, M. C. Protocolos de avaliação de letramento, narrativa e consciência fonológica elaborados para o estágio supervisionado em atenção primária em Fonoaudiologia - programa escola do curso de Fonoaudiologia da FMUSP. 1998. Não publicado.

BRYANT, P.; NUNES, T.; BINDMAN, M. The relations between children's linguistic awareness and spelling: the case of the apostrophe. Reading and Writing, v. 12, n. 3, p. 253-276, 2000

CAPELLINI, S. A.; CIASCA, S. M. Avaliação da consciência fonológica em crianças com distúrbio específico de leitura escrita e distúrbio de aprendizagem. Temas sobre Desenvolvimento, v. 8, n. 48, p. 17-23, 2000.

CAPOVILLA, A. G. S. Intervenção em dificuldades de leitura e escrita como tratamento de consciência fonológica. In: SANTOS, M. T. M.; NAVAS, A. L. G. P. Distúrbios de leitura ra escrita teoria e prática. São Paulo: Manole, 2002a.

CAPOVILLA, A. G. S. Leitura e escrita como fatores de inclusão: comparando a eficácia dos métodos fônico e global de alfabetização. Revista Psicopedagogia, v. 19, n. 60, p. 4-24, 2002 b.

CIELO, C. A. Habilidades em consciência fonológica em crianças de 4 a 8 anos de idade. Pró-Fono Revista de Atualização Científica, Barueri, SP, v. 14, n. 3, p. 301-312, set.-dez. 2002.

GILBERTSON, M.; BRAMLETT, R. K. Phonological awareness screening to identify at-risk readers: implications for practitioners. Language, Speech, and Hearing Services in Schools, v. 29, n. 2, p. 109-116, apr. 1998.

GODOY, D. M. A. O papel da consciência fonológica no processo de alfabetização. Pró-Fono Revista de Atualização Científica, Barueri, SP, v. 15, n. 3, p. 241-250, set.-dez. 2003.

HOFFMAN, P. R. Phonological intervention within storybook reading. Topics in Language Disorders, v. 17, n. 2, p. 69-88, 1997.

MARCUSCHI, L. A. Oralidade e letramento. In: MARCUSCHI, L. A. Da fala para a escrita: atividades de retextualização. 2. ed. São Paulo: Cortez, 2001.

SALLES, J. F.; PARENTE, M. A. M. Relação entre os processos cognitivos envolvidos na leitura de palavras e as habilidades de consciência fonológica em escolares. PróFono Revista de Atualização Científica, Barueri, SP, v. 14, n. 2, p. 175-186, maio-ago. 2002.

SAVAGE, R.; CARLESS, S.; STUART, M. The effects of rime and phoneme based teaching delivered by learning support assistants. Journal of Research in Reading, v. 26, n. 3, p. 211-233, 2003.

SAVAGE, R.; CARLESS, S. Predicting curriculum and test performance at age 7 years from pupil background, baseline skills and phonological awareness at age 5. British Journal of Educational Psychology, v. 74, n. 2, p. 155-171, 2004. SOARES, M. O que é letramento e alfabetização. In: SOARES, M. Letramento: um tema em três gêneros. Belo Horizonte: Autêntica, 1998.

Endereço para correspondência:

Maria Sílvia Cárnio

R. Corinto, 543, apto. 27 B1. A - Vila Indiana - São Paulo - SP - CEP: 05586-060. 